\title{
Drivers for Recycling in Johannesburg, South Africa
}

\author{
Thea Schoeman and Mbali Zwane
}

\begin{abstract}
Cities worldwide are facing accelerated rates of municipal waste generation which has become a matter of global environmental management concern. The City of Johannesburg (CoJ) faces numerous barriers in the sustainable management of waste and has 4.54 years airspace left in landfills. To divert waste from landfill the $\mathrm{CoJ}$ started a recycling program that requires households to separate waste at source. This study firstly investigated the influence of gender, employment status and education level on recycling participation. A total of 1019 respondents participated in this part of the study and completed a self-administered questionnaire. For each of the independent variables an analysis was conducted using cross tabulation and chi-square test for independence. The results showed that employment status $\left(\chi^{2}(1)=14.851, p=.0, p h i=.121\right)$ and education level $\left(\chi^{2}(1)=15.666, p=.0\right.$, phi $\left.=-.124\right)$ had a significant influence on recycling participation. The second part of this study determined the attitude and perceived control of 403 individuals in separating waste at source. Respondents showed an overwhelming positive attitude towards recycling with $74.1 \%$ strongly agreeing that recycling is good and $72.0 \%$ that recycling is useful. Although respondents indicated positive perceived behavioral control, only $23.9 \%$ strongly agreed that recycling is easy and $27.3 \%$ knew what items to recycle.
\end{abstract}

Keywords-Attitude, perceived control, recycling behavior, situational variables, waste separation at source.

\section{INTRODUCTION}

Waste generation is a global problem with approximately 2.01 billion tonnes of waste generated globally and only $33 \%$ of it disposed of or treated in an environmentally sustainable manner [1]. Integrated sustainable waste management (ISWM) in developing countries is a difficult task as municipalities are faced with issues of urbanization, industrialization, constantly changing lifestyles, and rapid population growth - factors that [2] identified as constraints to proper waste management. Reference [3] identified environmental, financial, technical, socio-cultural, legal as well as institutional factors as aspects that affect sustainable waste management.

The city of Johannesburg (CoJ) faces the same waste management challenges as other urban areas. The population growth in the $\mathrm{CoJ}$ attributed to the increase in waste generation as well as the decrease in the availability of land for landfill sites [4]. It is estimated that there is 4.54 years airspace left in

Manuscript received September 29, 2020.

Thea Schoeman is with Geography, Environmental Management \& Energy Studies, University of Johannesburg (UJ), PO Box 524, Auckland Park, 2006. Mbali Zwane is a Geography honors student at UJ. landfills in the CoJ [5]. These constrains have therefore led the city to consider other waste management options that focus mainly on diverting waste from landfill sites [6]. The city implemented the separation at source $(\mathrm{S} @ \mathrm{~S})$ recycling program that encourages residents to separate household waste for recycling [7].

Separating waste at source for recycling is an important component of ISWM and to reduce the amount of waste to landfill. Socio-demographic factors and psychological variables of individuals can assist in understanding and predicting recycling behaviour. This study therefore investigated the influence of gender, employment status and education level on recycling participation in Johannesburg. It further determines the attitude and perceived control of individuals in separating waste at source.

\section{LITERATURE REVIEW}

Waste generation in South Africa has increased drastically and approximately 54.2 million tons (Mt) of waste was generated in 2017 [8]. The CoJ is in Gauteng - the smallest province in South Africa. According to [9], it is estimated that Gauteng contributes approximately $45 \%$ of the total municipal solid waste generated in the country. Landfilling is still the most considered option of waste management even when cities such as $\mathrm{CoJ}$ are running out of airspace in landfill sites. The National Waste Management Strategy (NWMS) was approved in 2011 and promotes waste minimization, reuse, recycling and recovery of waste in South Africa [10].

The CoJ committed to achieving the goals of the NWMS and has developed waste management strategies that are in line with the NWMS [11]. One of the goals of the $\mathrm{CoJ}$ is a $20 \%$ reduction of waste disposed to landfills by 2020 . However, the majority of the 1101088 tons of waste collected in the city is still disposed of in landfill sites [5]. The S@S program diverted 83 104 tons waste in the 2018/19 financial year, which is a decrease when compared to the 94344 tons that was diverted for the 2017/18 financial year [5]. The target of the S@S program by the $\mathrm{CoJ}$ was to achieve a diversion of 122550 tons, but due to the lack of participation in waste separation from households the target was not reached [5]. The latest figure available for recycling participation in the $\mathrm{S} @ \mathrm{~S}$ program is very low at an average of $19.9 \%$ [11].

Reference [12] states that recycling programs often focus only on the technical aspects and argues that the needs of households should play a key role in designing such programs. They state that technical systems may not be relevant for different cultures and contexts. It is therefore necessary to 
investigate drivers of waste separation at source as household involvement in recycling is necessary for the success of a recycling program. Knowing which personal attributes are associated with waste separation behavior can assist in designing programs that would increase participation in recycling [13]. There are different drivers that influence recycling participation and [14], [15] grouped the different variables into three broad groups - environmental values, situational variables and psychological factors. Two of these groups of variables were investigated in this study, namely situational variables and psychological factors.

\section{A. Situational variables}

Situational factors are variables that represent a person's situation and it give shape to their environmental action. These includes a variety of variables such as access to recycling programs and facilities (contextual factors), or socio-demographic factors such as age, gender, income, etc. Studies on recycling behavior agree that socio-demographic factors play a major role in recycling behaviour, but there is uncertainty on how socio-demographic variables influence recycling [12], [16], [17]. It therefore necessitates that the influence of socio-demographic variables is determined as it is a significant predictor of recycling behavior [18]. This study investigated gender, education level and employment status as situational variables that influence recycling participation.

Generally, women are more concerned about the environment and often participate more than men in pro-environmental behaviour. However, specific findings on the role of gender in recycling participation show mixed results. Reference [19] found that while women demonstrated a greater concern for the environment, there was very little difference in the recycling participation of women and men. On the other hand, [20] found that being female increases the likelihood to recycle and that gender is one of the key significant and important coefficients.

Previous studies on the influence of education level on waste separation at household level came to different conclusions. References [21] and [22] identified education level to be the socio-demographic variable that had the largest influence on recycling participation. Contrastingly, [23] and [24] found that education was not an important determinant for separating waste for recycling. Reference [25] found that full-time employed people are likely to spend less time on recycling activities and [26] state that recyclers are more likely to come from retired households.

\section{B. Psychological factors}

One category of research often took place in the social research field and investigated psychological aspects of recycling behavior. Psychological factors that were identified by researchers such as [20], [27], [28], [29] include attitude, social norm, perceived control, concern for the community, subjective norm and consequences of recycling. Reference [19] showed that an individual's attitude is a major determinant of recycling behaviour. They further state that attitude is influenced by knowledge of recycling facilities, having time to separate waste and space to store recyclables. Similar results were obtained by [27] that found that attitude towards recycling impacts an individual's participation in a curbside recycling scheme.

Perceived control is defined by [19] as an individual's perception of their ability to perform waste separation at source. Their finding showed that perceived control strongly correlates with recycling participation. The greater perceived control is, the stronger should be a person's willingness to separate waste for recycling. Reference [30] concluded that perceived behavior control was the strongest predictor of the intention to recycle.

\section{Study AREA AND Methodology}

\section{A. Study area}

The CoJ is the largest metropolitan municipality with the largest population in South Africa and covers an area of 1645 $\mathrm{km}^{2}$ with a population density of 3009 persons $/ \mathrm{km}^{2}$ [31]. Johannesburg has approximately 5.5 million residents in 1.85 million households [32]. The population growth rate in the CoJ is $2.91 \%$ per annum, which is nearly double the population growth rate of South Africa [32]. The growth can be attributed to the fact that the city is the economic and financial hub of the country, therefore people move to the city because of the economic opportunities that it offers [33].

Pikitup is the waste management service provider and is wholly owned by the CoJ. It provides waste management services to 1182997 formal households and 157 informal settlements [5]. The Pikitup waste infrastructure consists of 12 depots across the seven regions of the CoJ, six sorting facilities and buy-back centers, 42 drop-off/garden sites, four operational landfill sites and two closed landfill sites [32]. In addition, two privately owned landfill sites (Mooiplaats and Chloorkop) in the north of the CoJ are also used for waste disposal. Currently the $\mathrm{CoJ}$ has two programs available to residents for separation of dry recyclables. The first is the curbside S@S program and the second is drop-off facilities across the city. Pikitup implemented a pilot S@S project in October 2009 at the Waterval Depot. The S@S program was extended and now covers 570312 households and nine of the depots in CoJ [11].

\section{B. Methodology}

A mixed method research approach was used to conduct this study and collected both qualitative and quantitative results. Both data types were collected during the same timeframe and therefore can be considered as a concurrent mixed method design [34]. The advantages of mixed methods research have led to its acceptance and use across varied disciplines, including recycling behavior and previous studies used a mixed methods approach [16], [27], [35].

Two questionnaires were used for this study. The first questionnaire tested recycling behavior and included socio-demographics factors. For both questionnaires, the convenience sampling scheme was used. A total of 1019 respondents completed this self-administered paper questionnaire. The second questionnaire tested drivers that influence participation in recycling and a total of 403 respondents completed this questionnaire using an online 
platform. This questionnaire included attitude and perceived control in separating waste at source.

Descriptive statistical techniques were used to organize and summarize data for enhancing the understanding of the results. A multivariate analysis was performed to determine the relationship between gender, employment status and education level and waste separation behavior. For each of the independent variables, an analysis was conducted using cross tabulation and chi-square test $\left(\chi^{2}\right)$ for independence. The minimum requirement of at least five expected values per cell in the contingency tables were met for the use of $\chi^{2}$ to test for statistical significance at the $95 \%$ confidence level. The phi correlation coefficient ( $p h i$ ) was used to measure the strength of association between two variables. The values for $p h i$ can range from 0 to +1.0 - where a value of 1.0 means there is a perfect one-to-one correlation between two variables.

\section{RESUlTS AND DISCUSSION}

Three socio-demographic variables (gender, employment status and education level) were investigated in this study. For each of the socio-demographic variables, two hypotheses were tested. The null hypothesis is that no relationship exists on the categorical variables and recycling, while the alternative hypothesis is that a socio-demographic variable significantly influences participation in recycling. A $p$-value determines if there is a significant relationship between variables and a $p$-value of less than 0.05 indicates a significant relationship with a $95 \%$ confidence level. It further determined the attitude and perceived control as determinants of recycling participation.

\section{A. Demographic characteristics}

Table 1 summarizes the demographic characteristics of the recycling behavior questionnaire. More females (55.2\%) than males $(44.8 \%)$ participated in the study. Economically inactive respondents $(39.7 \%)$ included pensioners, students, homemakers and the unemployed. Education level was grouped into respondents that completed schooling up to Matric (the final year of high school and the qualification obtained on graduating from high school In South Africa) and those that were part- or full-time employed $(60.3 \%)$.

TABLE I: DEMOGRAPHIC CHARACTERISTICS

\begin{tabular}{|c|c|c|}
\hline Characteristics & Class & $\%$ \\
\hline Gender & Female & 55. \\
& Male & 2 \\
& & 44. \\
& & 8 \\
\hline Employment & Economically inactive & 39. \\
& Part- and full-time & 7 \\
& & 60. \\
& & 3 \\
\hline Education & Up to Matric & 41. \\
& Post-matric & 8 \\
& & 58. \\
& & 2 \\
\hline
\end{tabular}

\section{B. Gender}

The cross tabulation (Table 2) shows that there is no significant difference in the participation in recycling between the genders. There is only a $1.7 \%$ difference between the female and male participation in recycling with female participation slightly higher at $47.9 \%$.

TABLE II: GENDER AND RECYCLING

\begin{tabular}{|c|c|c|}
\hline Recycle & $\begin{array}{c}\text { Female } \\
(\%)\end{array}$ & $\begin{array}{c}\text { Male } \\
(\%)\end{array}$ \\
\hline Yes & 47.9 & 46.2 \\
\hline No & 52.1 & 53.8 \\
\hline
\end{tabular}

The following hypotheses were tested:

$H_{0}$ : There is no association between gender and participation in recycling.

$H_{a}$ : Gender influences participation in recycling.

The results of the chi-square test for independence were $\chi^{2}(1)$ $=.29, p=.59$, $p h i=.017$. Thus, there is no association between gender and separating household waste for recycling and the null hypothesis is accepted. The result of this study is therefore in agreement with previous studies that found that gender does not play a role in waste separation at source [16], [19], [24], [36]. The CoJ thus does not have to take into consideration the gender of residents when developing, expanding and promoting the $\mathrm{S} @ \mathrm{~S}$ program.

\section{Employment status}

The cross tabulation (Table 3) shows noticeable differences in the waste separation behaviour of employed and economically inactive respondents. Respondents that were employed participated at a meaningfully higher rate $(52.0 \%)$ in waste separation than economically inactive respondents with only $39.7 \%$.

TABLE III: EMPLOYMENT STATUS AND RECYCLING

\begin{tabular}{|c|c|c|}
\hline Recycle & Employed (\%) & Unemployed (\%) \\
\hline Yes & 52.0 & 39.7 \\
\hline No & 48.0 & 60.3 \\
\hline
\end{tabular}

The following hypotheses were tested:

$H_{0}$ : There is no association between employment status and participation in recycling.

$H_{a}$ : Employment status influences participation in recycling.

The results of the chi-square test for independence were $\chi^{2}(1)$ $=14.851, p=.0, p h i=.121$. The null hypothesis is rejected and the result show that there is a statistically significant relationship between employment status and waste separation behaviour. The result is in contrast with the [25] study that found that full-time employed people are likely to spend less time on recycling activities when compared to unemployed people. One would assume that unemployed people would have more time to separate household waste for recycling. This is clearly not the case in this study. 


\section{Education level}

The cross tabulation (Table 4) shows a $12.5 \%$ difference in separation of waste for recycling between respondents with an education level up to Matric (40.0\%) and those with a post-matric qualification $(52.5 \%)$.

TABLE IV: EDUCATION LEVEL AND RECYCLING

\begin{tabular}{|c|c|c|}
\hline Recycle & Up to Matric (\%) & Post-matric (\%) \\
\hline Yes & 40.0 & 52.5 \\
\hline No & 60.0 & 47.5 \\
\hline
\end{tabular}

The following hypotheses were tested:

$H_{0}$ : There is no association between education level and participation in recycling.

$H_{a}$ : Education level influences participation in recycling.

The results of the chi-square test for independence were $\chi^{2}(1)$ $=15.666, p=.0$, phi $=-.124$. Thus, education level has a significant positive influence on recycling participation. The null hypothesis is rejected and education level influences participation in separating waste at household level in Johannesburg. Similar results were obtained in previous studies - education level was found by [18], [20], [25], [37] to be an important determinant for participation in recycling.

\section{E. Attitude}

Respondents attitude towards recycling were tested in four questions - recycling is good, useful, rewarding, and responsible (Table 5). If an individual exhibits a positive attitude towards waste separation at source, such individual will consistently participate in recycling. In studies conducted by [38], [39] the results found that a positive attitude towards recycling improves recycling participation. Recycling is good had the highest positive attitude with $88.3 \%$ of respondents agreeing or strongly agreeing with this statement. Recycling is rewarding attracted the lowest level with just more than half $(52.7 \%)$ strongly agreeing with this statement. Overall respondents exhibited a strong positive attitude towards recycling.

\section{F. Perceived control}

Perceived control is a person's perception of difficulty in participating in waste separation at household level. Perceived difficulties in separating waste at source was found by [40] as an important driver in explaining residents' behavior and participation in recycling. Five questions addressed perceived control over recycling and included respondents' perception on the ease of recycling, opportunities to recycle and knowledge on how to recycle and what items can be recycled (Table 6). The responses indicated that overall, they perceived to have control over their participation in recycling. However, more than a quarter $(26.5 \%)$ of respondents disagreed or strongly disagreed that recycling is easy. Opportunities to recycle also drew a $20.8 \%$ negative response.

\section{CONCLUSION AND RECOMMENDATION}

Two of the socio-demographic factors investigated had a significant influence on participation in recycling, namely employment status and education level. Contrary to previous studies that found that been employed had a negative correlation with separating waste at household level for recycling, the finding of this study showed that employed respondents participated more in recycling than economically inactive respondents. Respondents had an overwhelmingly positive attitude towards recycling. Furthermore, the majority perceived to have control over participation in recycling. However, more than a quarter of respondents indicated that they did not find recycling to be an easy process.

The data collected for the second questionnaire that investigated attitude and perceived control took place while South Africa was under Lockdown Level 4 and social media and an online platform was used to collect the data. Of the 403 respondents that participated in the study, $90.1 \%$ indicated that they separated waste for recycling. This is not a true reflection of the reported recycling participation rates recorded in previous studies on recycling in Johannesburg [24] and the rates reported by Pikitup [11]. It is therefore necessary that further research is done investigating psychological factors that drives participation in waste separation at source. Such research should ensure that both individuals with positive and negative behavior are included in the study.

TABLE V: ATTITUDE TOWARDS RECYCLING

\begin{tabular}{|c|c|c|c|c|}
\hline Agreement & $\begin{array}{c}\text { Recycling is good } \\
(\%)\end{array}$ & $\begin{array}{c}\text { Recycling is useful } \\
(\%)\end{array}$ & $\begin{array}{c}\text { Recycling is } \\
\text { rewarding }(\%)\end{array}$ & $\begin{array}{c}\text { Recycling is } \\
\text { responsible }(\%)\end{array}$ \\
\hline Strongly disagree & 8.0 & 8.2 & 7.0 & 8.1 \\
\hline Disagree & 1.5 & 1.0 & 1.5 & 1.0 \\
\hline Neutral & 2.2 & 1.5 & 13.0 & 2.8 \\
\hline Agree & 14.2 & 17.3 & 25.8 & 18.6 \\
\hline Strongly agree & 74.1 & 72.0 & 52.7 & 69.5 \\
\hline
\end{tabular}


TABLE VI: PERCEIVED CONTROL

\begin{tabular}{|c|c|c|c|c|c|}
\hline Agreement & $\begin{array}{c}\text { Recycling is } \\
\text { easy (\%) }\end{array}$ & $\begin{array}{c}\text { I have plenty } \\
\text { opportunities to } \\
\text { recycle (\%) }\end{array}$ & $\begin{array}{c}\text { Recycling is } \\
\text { convenient (\%) }\end{array}$ & $\begin{array}{c}\text { I know what } \\
\text { items can be } \\
\text { recycled (\%) }\end{array}$ & $\begin{array}{c}\text { I know how to } \\
\text { recycle my } \\
\text { waste (\%) }\end{array}$ \\
\hline Strongly disagree & 7.6 & 7.5 & 3.1 & 8.1 & 7.5 \\
\hline Disagree & 18.9 & 13.3 & 15.1 & 7.0 & 9.8 \\
\hline Neutral & 18.4 & 17.8 & 19.6 & 13.5 & 18.3 \\
\hline Agree & 31.2 & 32.8 & 32.5 & 44.1 & 40.2 \\
\hline Strongly agree & 23.9 & 28.6 & 29.7 & 27.3 & 24.1 \\
\hline
\end{tabular}

\section{REFERENCES}

[1] Kaza, S., Yao, L., Bhada-Tata, P. \& Van Woerden, F. 2018. What a waste 2.0: A global snapshot of solid waste management to 2050. World Bank Urban Development Series. Washington, DC: World Bank Group. https://doi.org/10.1596/978-1-4648-1329-0

[2] Mmereki, D., Baldwin, A. \& Li, B. 2016. A comparative analysis of solid waste management in developed, developing and lesser eveloped countries. Environmental Technology Reviews, 5(1):120-141. https://doi.org/10.1080/21622515.2016.1259357

[3] Guerrero, L.A., Maas, G. \& Hogland, W. 2013. Solid waste management challenges for cities in developing countries. Waste Management, 33(1):220-232 https://doi.org/10.1016/j.wasman.2012.09.008

[4] Rasmeni, Z.Z. \& Madyira, D.M. 2019. A review of the current municipal waste management practices in Johannesburg city townships. Procedia Manufacturing, 35, 1025-1031. https://doi.org/10.1016/j.promfg.2019.06.052

[5] Pikitup. 2020. Pikitup Johannesburg SOC Limited Integrated Annual Report 2018/19. Available from: http://www.pikitup.co.za/ wp-content/uploads/2020/05/2018-2019-Pikitup-IAR.pdf.

[6] CoJ (City of Johannesburg). 2011. Integrated waste management policy. Available from: https://joburg.org.za/2011/pdfs/iwm_policy2011.pdf.

[7] Pikitup. 2015. Separation@Source programme. Available from: http://www.pikitup.co.za/seperationsource/.

[8] DEA (Department of Environmental Affairs). 2018. South Africa State of Waste Report - Second draft report. Available from: http://sawic.environment.gov.za/documents/9066.pdf.

[9] Oelofse, S., Muswema, A., Ramukhwatho, F. 2018. Household food waste disposal in South Africa: A case study of Johannesburg and Ekurhuleni. South African Journal of Science, 114(5/6). https://doi.org/10.17159/sajs.2018/20170284

[10] DEA (Department of Environmental Affairs). 2011. National Waste Management Strategy. Pretoria: South Africa.

[11] Pikitup. 2016. Pikitup Johannesburg SOC Limited 2016/2017 midyear performance report. Available from: http://www.pikitup.co.za/wpcontent/uploads/2015/08/2016-2017-Mid-year-Performance-Report-Dec ember-2016.pdf.

[12] Rousta, R. \& Bolton, K. 2019. Chapter 8 - Sorting household waste at the source. In Sustainable resource recovery and zero waste approaches:105-114. Edited by Taherzadeh, M.J., Bolton, K., Wong, J. \& Pandye, A. Amsterdam: Elsevier. https://doi.org/10.1016/B978-0-444-64200-4.00008-6

[13] Anderson, B.A., Romani, J.H., Wentzel, M. \& Phillips, H.E. 2013. Recycling behaviour among urban South Africans: The role of race and social status. Population Studies Center Research Report No. 1-790.

[14] Barr, S. 2002. Household waste in social perspective: Values, attitudes, situation and behaviour. Burlington: Ashgate.

[15] Barr, S. 2007. Factors influencing environmental attitudes and behaviors. A UK case study of household waste management. Environment and Behaviour, 39(4):435-473. https://doi.org/10.1177/0013916505283421

[16] Miafodzyeva, S. 2012. Understanding the recycling behaviour of householders in multicultural urban areas: Caste study Järva,
Stockholm. Licentiate Thesis. Stockholm: KTH Royal Institute of Technology.

https://doi.org/10.1177/0734242X13476746

[17] Starr, J. \& Nicolson, C. 2015. Patterns in trash: Factors driving municipal recycling in Massachusetts. Resources, Conservation and Recycling, 99:7-18.

https://doi.org/10.1016/j.resconrec.2015.03.009

[18] Latif, S.A., Omar, M.S., Bidin, Y.H. \& Awang, Z. 2013. Analyzing the effect of situational factor on recycling behaviour in determining the quality of Life. Journal of Asian Behavioural Studies, 3(8), 37-46.

[19] Tonglet, M., Phillips, P.S. \& Bates, M.P. 2004. Determining the drivers for householder pro-environmental behaviour: Waste minimisation compared to recycling. Resources, Conservation and Recycling, 42(1):27-48. https://doi.org/10.1016/j.resconrec.2004.02.001

[20] Fiorillo, D. 2013. Household waste recycling: National survey evidence from Italy. Journal of Environmental Planning and Management, 56(8):1125-1151. https://doi.org/10.1080/09640568.2012.709180

[21] Jenkins, R.R., Martinez, S.A., Palmer, K. \& Poodolsky, M.J. 2003. The determinants of household recycling: A material specific analysis of recycling program features and unit pricing. Journal of Environmental Economics and Management, 45(2):294-318. https://doi.org/10.1016/S0095-0696(02)00054-2

[22] Babaei, A.A., Alavi, N., Goudarz, G., Teymouri, P., Ahmadi, K. \& Rafiee, M. 2015. Household recycling knowledge, attitudes and practices towards solid waste management. Resources, Conservation and Recycling, 102:94-100. https://doi.org/10.1016/j.resconrec.2015.06.014

[23] Tabernero, C., Hernández, B., Cuadrado, E. \& Luque, B. 2015. A multilevel perspective to explain recycling behaviour in communities. Journal of Environmental Management, 159:192-201. https://doi.org/10.1016/j.jenvman.2015.05.024

[24] Schoeman, T. \& Schmidt, J. 2016. An explorative study on household recycling behaviour in the City of Johannesburg. Proceedings of the Centenary Conference of the Society of South African Geographers. Stellenbosch, South Africa, 25-28 September 2016. Available from: http://www.ssag.co.za/wp-content/uploads/2019/06/proceedings-final-2 016.pdf.

[25] Sidique, S.F., Joshi, S.V. \& Lupi, F. 2010. Factors influencing the rate of recycling: An analysis of Minnesota counties. Resources, Conservation and Recycling, 54(4):242-249. https://doi.org/10.1016/j.resconrec.2009.08.006

[26] Mavropoulus, A. 2009. Recycling behaviour: The present focus brain and a framework to understand personal differences in recycling. Proceedings of ISWA World Conference, 2009.

[27] Barr, S., Ford, N.J. \& Gilg, A.W. 2003. Attitudes towards recycling household waste in Exeter, Devon: Quantitative and qualitative approaches. Local Environment, 8(4):407-421. https://doi.org/10.1080/13549830306667

[28] Zen, I.S., Noor, Z.Z. \& Yusuf, R.O. 2014. The profiles of household solid waste recyclers and non-recyclers in Kuala Lumpur, Malaysia. Habitat International, 42:83-89. https://doi.org/10.1016/j.habitatint.2013.10.010

[29] Knickmeyer, D. 2020. Social factors influencing household waste separation: A literature review on good practices to improve the recycling 
performance of urban areas. Journal of Cleaner Production, 245(2020): 118605 .

https://doi.org/10.1016/j.jclepro.2019.118605

[30] Mahmud, S.N.D. \& Osman, K. 2010. The determinants of recycling intention behavior among the Malaysian school students: An application of theory of planned behavior. Procedia - Social and Behavioral Sciences, (9):119-124. https://doi.org/10.1016/j.sbspro.2010.12.123

[31] CoJ (City of Johannesburg). 2018. World Environment Day: We must work together to beat plastic pollution. https://www.joburg.org.za/.

[32] CoJ (City of Johannesburg). 2020. City of Johannesburg Annual Report 2018/19. Available from: https://www.joburg.org.za/.

[33] CoJ (City of Johannesburg). 2019. City of Johannesburg Annual Report 2017/18. Available from: https://www.joburg.org.za/.

[34] Onweugbuzie, A.J. \& Collins, K.M. 2007. A typology of mixed methods sampling designs in social science research. The Qualitative Report, 12(2):281-316.

[35] Bolaane, B. 2006. Constraints to promoting people centred approaches in recycling. Habitat International, 30(4):731-740. https://doi.org/10.1016/j.habitatint.2005.10.002

[36] Wang, Z., Dong, X. \& Yin, J. 2018. Antecedents of urban residents' separate collection intentions for household solid waste and their willingness to pay: Evidence from China. Journal of Cleaner Production, 173(2018):256-264 https://doi.org/10.1016/j.jclepro.2016.09.223

[37] Babaei, A.A., Alavi, N., Goudarz, G., Teymouri, P., Ahmadi, K. \& Rafiee, M. 2015. Household recycling knowledge, attitudes and practices towards solid waste management. Resources, Conservation and Recycling, 102:94-100. https://doi.org/10.1016/j.resconrec.2015.06.014

[38] Corsini, F., Gusmerotti, N.M., Testa, F. \& Iraldo, F. 2018. Exploring waste prevention behaviour through empirical research. Waste Management, 79:132-141. https://doi.org/10.1016/j.wasman.2018.07.037

[39] Jekria, N. \& Daud, S. 2016. Environmental concern and recycling. Procedia Economics and Finance, 35:667-673. $7^{\text {th }}$ International Economics and Business Management Conference, 5-6 October 2015. https://doi.org/10.1016/S2212-5671(16)00082-4

[40] Nguyen, T.T.P., Zhu, D. \& Le, N.P. 2015. Factors influencing waste separation intention of residential households in a developing country: Evidence from Hanoi, Vietnam. Habitat International, 48:169-176. https://doi.org/10.1016/j.habitatint.2015.03.013 